\title{
Association between feeding habits and severe - early childhood caries in children up to 24 month old
}

\author{
Marija Obradović, Olivera Dolić, Jovan Vojinović, Slava Sukara \\ University of Banja Luka, Faculty of Medicine, Department of Pediatric and Preventive dentistry, Banja Luka, Republika \\ Srpska, Bosnia and Herzegovina
}

\begin{abstract}
SUMMARY
Introduction During the first two years of life children's nutrition is mostly based on frequent, liquid and sweetened meals which can cause Severe-Early Childhood Caries (S-ECC) development. The aim of this research was to determine the relationship between dietary habits and S-ECC in children up to 24 month-old living in Banja Luka, Bosnia and Herzegovina.

Methods Cross-sectional study included representative sample of 192 children. Before dental examination of children, each parent/caregiver was interviewed about the basic info, socio-demographic characteristics and children 's eating habits. The questionnaire was conducted as interview ("face to face"). Subjects were divided into two groups: the first group - children with S-ECC and the second group - caries free children. For statistical analysis and presentation of results SPSS 16.0 for Windows, MS Office Word and Microsoft Office Excel were used.

Results In the study sample $34.9 \%$ of children were suffering from S-ECC. About $50 \%$ of children who were breast-fed at night after first tooth eruption had S-ECC. The use of baby bottle with milk or other sweetened content during bedtime and during the night was identified as significant caries risk factor $(P<0.05)$.

Conclusion Nighttime breastfeeding, use of bottle with milk during bedtime/nighttime or other sweetened content during night after eruption of first primary tooth were strongly associated with S-ECC in the examined children.
\end{abstract}

Keywords: breastfeeding; Severe - Early Childhood Caries; nighttime breastfeeding; baby bottle; risk factors

\section{INTRODUCTION}

Early childhood is crucial for proper development and maintaining oral health. Early childhood caries (ECC) is one of major public health problems in the world [1-7]. According to the research it is one of the most common chronic infectious disease in early childhood that is due to its multifactorial etiology difficult to control $[8,9]$.

Aggressive form of the disease - Severe Early Childhood Caries (S-ECC) can occur as soon as the deciduous tooth appears in the mouth, with localization on caries immune sites or smooth surfaces of the tooth [10]. The disease mostly begins as an off-white chalky change on the vestibular surface of the enamel along the gum line and sometimes on oral surface of primary maxillary incisors. Caries destruction of the tooth can be quite rapid and soon it can spread on other teeth. If child does not receive an appropriate treatment the disease can lead to pulp involvement, pain and other complications.

Similar to other forms of tooth decay S-ECC etiology includes interaction of three main factors: cariogenic microorganisms, fermentable carbohydrates and a host (tooth) during period of time [11]. Besides, specificities of an early age, like immature immune system, newborn teeth in the stage of post eruptive mineralization, hy- poplastic changes, a special type of food (mostly liquid based) are considered to be risk factors for S-ECC development $[12,13]$. In addition to primary risk factors, there is a wide range of secondary factors that can indirectly contribute to development of carious lesions in primary teeth, but they are still under investigation [8-10].

Breastfeeding is natural, desirable type of feeding of a newborn and undoubtedly has great impact on overall health and development. Human milk is specific and its composition ideally suits human babies, opposite to substitutions of different origin (adapted infant formula, animal milk) that differs greatly in content. Breastfeeding is of great significance for proper growth, it provides optimal nutritional ingredients, immune protection to infants, and minimizes economic impact on families. The World Health Organization recommends breastfeeding until 24 months of age [14]. However, the American Academy of Pediatric Dentistry (AAPD) recommends that breastfeeding should stop around 12 months of age, even before, as soon as the first primary tooth erupts (around six months of age), because they consider that a longer duration of this habit contribute to development of an aggressive form of Early Childhood Caries (S-ECC) [10].

Children's diet in the first two years of life is mostly based on frequent, liquid and often sweetened meals. 
A special role in the etiology of dental caries in early childhood plays an inappropriate use of baby bottle especially during bedtime and nighttime. When a child falls asleep, liquid from a bottle is poured onto maxillary incisors, representing an outstanding basis for the development of cariogenic bacteria, especially because during the night the secretion of saliva is reduced [15].

In Banja Luka, Republic of Srpska, there is no organized prevention program in dentistry. There is no systematic oral health promotion and education of parents, there is lack of data regarding dental pathology and related risk factors in an early age because the practice of the first dental visit around the first birthday is not yet established. Unfortunately, the first dental examination is required only when enrolling into primary school.

The aim of this study was to determine relationship between dietary habits and development of Severe-Early Childhood Caries (S-ECC) in children up to 24-month-old living in Banja Luka, Bosnia and Herzegovina.

\section{MATERIAL AND METHODS}

The survey was conducted among children up to 24 month old, between July 2012 and July 2013. The crosssectional retrospective study included 192 children of both genders that represented $10 \%$ sample (even slightly larger) of a total of 1,820 children born and living in the city of Banja Luka during the period of 2011 to 2012. The study was conducted in the Public Health Center of Banja Luka. Necessary approval of the General Director and Ethical Committee of the Public Health Center of Banja Luka was obtained before the initiation of research.

Inclusion criteria of the study were: the presence of at least two fully erupted primary teeth in a healthy child and parental consent for participation. Respondents were selected randomly. Healthy children who were visiting regular pediatric checkups in Public Health Center of Banja Luka were referred to the specialist of pediatric and preventive dentistry for the evaluation of risk factors for Severe Early Childhood Caries. First dental visits of children were conducted in a separate office near the pediatric ambulance of Public Health Center. Every child was examined and parent interviewed, but only children who passed the inclusion criteria were included in further research.

Before dental examination of a child, a parent/caregiver was interviewed. A total of 192 questionnaires was filled and subsequently analyzed. Interviews were conducted "face to face" by a single researcher. Questionnaire consisted of two separate parts: the first contained questions related to general information of patient, sociodemographic information, dietary information such as breastfeeding and use of bottles. The second part was Dental record. Issues related to eating habits (breastfeeding and use of bottle) as possible risk factors for S-ECC were considered for the period after primary tooth eruption. Milk bottle referred to infant formula or animal milk (cow milk), and other sweetened content involved juices, milk porridge or sweetened tea. Research questionnaire was formed according to the guidelines of the American Academy of Pediatric Dentistry (AAPD) [16].

After completion of the interview, dental examination of children was conducted in the office with good natural light. Dental examinations were done in "knee to knee" position where parent and dentist seated opposite to each other so the child was lying with body and legs on the parent's lap, while the head was on the dentist's lap [17]. Oral examination was done using dental mirror and CPI periodontal probe (CPI-Community Periodontal Index). Sterile gauze swabs were used to dry the teeth, and remove dental biofilm. Carious changes on infant's teeth were diagnosed using the International Caries Detection and Assessment System (ICDAS), which is used for diagnosis and records of initial "white spot" carious lesions (without formed holes) to observable carious cavity [18]. Every surface of the tooth was examined and recorded in the second part of the Research Form. Only teeth that were fully present in one's mouth and all crown surfaces visible were taken into consideration.

After data collecting respondents were divided into two groups for the purpose of further analysis and assessment of S-ECCC risk factors. The first group consisted of children who had S-ECC (children with at least one active initial carious lesions on smooth surfaces of maxillary anterior teeth, according to AAPD) and the second group included completely healthy individuals without caries lesions (caries-free children) [10].

For statistical analysis and presentation of results SPSS 16.0 for Windows, MS Office Word and Microsoft Office Excel were used. The results were analyzed statistically by the Fisher's exact test, $\chi 2$ test (for checking linear growth), and binary logistic regression. Values of $\mathrm{p}<0.05$ were considered statistically significant.

\section{RESULTS}

A total of 192 children were examined, 99 (51.6\%) boys and 93 (48.4\%) girls up to 24 months of age. The prevalence of S-ECC in the sample was $34.9 \%$.

Socio-demographic characteristics of families are presented in the Table 1. Majority of mothers $(\mathrm{n}=117)$ had secondary school education or lower, which was significant for the occurrence of S-ECC. About 71.87\% of fathers also had secondary or lower school education, but this was not significant for the prevalence of caries in the examined sample. Monthly income below $1600 \mathrm{KM}$ - Convertible Marks ( $<818,06$ euro) reported $79.69 \%$ of families.

Most of examined children (89.58\%) were breastfed for at least one month $(n=172)$. There was no statistically significant difference in the S-ECC presence between children who were breastfed (34.3\%) or not (40.0\%) (Table 2). The children who were breast-fed four times per day or more $(n=41)$ were affected more by S-ECC $(36.6 \%)$ compared to those who had lower frequency of daily feedings (33.6\%) but this was not significant (Table 2). A half of respondents (50\%) who were breast-fed during the night had S-ECC. About $73.3 \%$ of those with S-ECC were breast-fed more than two times during the night. This 
Table 1. Socio-demographic characteristics of the tested sample Tabela 1. Sociodemografske karakteristike testiranog uzorka

\begin{tabular}{|c|c|c|c|}
\hline $\begin{array}{l}\text { Variable } \\
\text { Varijable }\end{array}$ & $\begin{array}{l}\text { S-ECC } \\
\text { Cirkularni } \\
\text { karijes } \\
\mathrm{n}(\%)\end{array}$ & $\begin{array}{l}\text { Caries-free } \\
\text { Bez karijesa } \\
\text { n (\%) }\end{array}$ & $\mathbf{p a}^{\mathbf{a}}$ \\
\hline \multicolumn{3}{|l|}{$\begin{array}{l}\text { Education of mothers } \\
\text { Obrazovanje majki }\end{array}$} & \multirow{3}{*}{$.013^{*}$} \\
\hline $\begin{array}{l}\text { High school or lower }(n=117) \\
\text { Srednja škola ili niže obrazovanje }\end{array}$ & $49(41.9)$ & $68(58.1)$ & \\
\hline $\begin{array}{l}\text { University education }(n=75) \\
\text { Univerzitetsko obrazovanje }\end{array}$ & $18(24.0)$ & $57(76.0)$ & \\
\hline \multicolumn{3}{|l|}{$\begin{array}{l}\text { Education of fathers } \\
\text { Obrazovanje očeva }\end{array}$} & \multirow{3}{*}{.130} \\
\hline $\begin{array}{l}\text { High school or lower }(n=138) \\
\text { Srednja škola ili niže obrazovanje }\end{array}$ & $53(38.4)$ & $85(61.6)$ & \\
\hline $\begin{array}{l}\text { University education }(n=54) \\
\text { Univerzitetsko obrazovanje }\end{array}$ & $14(25.9)$ & $40(74.1)$ & \\
\hline \multicolumn{3}{|l|}{$\begin{array}{l}\text { Monthly family income } \\
\text { Mesečna primanja porodice }\end{array}$} & \multirow{3}{*}{$<.001^{*}$} \\
\hline$<1600 \mathrm{KM}(<818.06$ euro $)(n=153)$ & $62(32.8)$ & $91(67.2)$ & \\
\hline$\geq 1600 \mathrm{KM}(\geq 818.06$ euro $)(n=39)$ & $5(12.8)$ & $34(87.2)$ & \\
\hline \multicolumn{4}{|c|}{$\begin{array}{l}\text { Fisher exact test (Education of mothers, Education of fathers), } \\
\chi 2 \text { test to check the } \\
\text { linear growth (monthly income) } \\
\text { *Statistically significant results }(p<0.05) \\
\text { Fišerov egzaktni test (obrazovanje majke, obrazovanje oca), } \\
\chi 2 \text { test za proveru linearnog rasta (Mesečna primanja) } \\
\text { *Statistički značajan rezultat }(p<0.05)\end{array}$} \\
\hline
\end{tabular}

was statistically significant (Table 2). S-ECC was present in $50 \%$ of children practicing bedtime baby bottle with milk (Table 3). Children who consumed sweetened liquid $(64.7 \%)$ or milk (54.2\%) in bottle during nighttime were also significantly more affected by S-ECC (Table 3 ).

\section{DISCUSSION}

The prevalence of ECC varies from $1 \%$ to $70 \%$ in different parts of the world and can be affected by many factors [2, $3,19,20]$. A survey conducted in Banja Luka from 2008 to 2010, among 2 to 6 year-old children attending the Centre for pre-school education of Banja Luka, demonstrated high prevalence of dental caries $(35.35 \%)$ where carious lesion was diagnosed on a level of already formed carious cavity. The largest percentage of affected teeth (92.69\%) was not treated [21]. However, this study did not cover children at infancy (up to 24 months-old) that is from the point of primary prevention the most important and initial caries lesions were not registered either. Leong et al. confirmed that factors occurring in the first year of life strongly influence the experience of early teeth decay, which particularly can be related to the eating habits of a child [9].

The prevalence of caries lesions in our research was high and included $34.9 \%$ of all respondents. Most of children came from families whose incomes were below average, considering that even $79.68 \%$ of the surveyed families had a monthly income less than $1600 \mathrm{KM}$ (below 818.06 euro). According to the data of the Republic of Srpska Institute of Statistics the average monthly net salary in the Republic of Srpska was around 825 KM (421.81 euro) [22]. This study shows a significant association between
Table 2. Distribution of children according to breastfeeding characteristics and appearance of S-ECC

Tabela 2. Klasifikacija dece na osnovu karakteristika dojenja i pojave cirkularnog karijesa

\begin{tabular}{|c|c|c|c|}
\hline $\begin{array}{l}\text { Variable } \\
\text { Varijable }\end{array}$ & $\begin{array}{l}\text { S- ECC } \\
\text { Cirkularni } \\
\text { karijes } \\
\mathrm{n}(\%) \\
\end{array}$ & $\begin{array}{l}\text { Caries-free } \\
\text { Bez karijesa } \\
\mathrm{n}(\%)\end{array}$ & $\mathbf{p a}^{\mathrm{a}}$ \\
\hline \multicolumn{3}{|l|}{$\begin{array}{l}\text { Breastfeeding (at least one month) } \\
\text { Dojenje (najmanje jedan mesec) }\end{array}$} & \multirow{3}{*}{.626} \\
\hline $\begin{array}{l}\text { Yes }(n=172) \\
\text { Da }\end{array}$ & $59(34.3)$ & $113(65.7)$ & \\
\hline $\begin{array}{l}\mathrm{No}(n=20) \\
\mathrm{Ne}\end{array}$ & $8(40.0)$ & $12(60.0)$ & \\
\hline \multicolumn{3}{|l|}{$\begin{array}{l}\text { Duration of breastfeeding } \\
\text { Uzrast do kojeg je trajalo dojenje }\end{array}$} & \multirow[b]{2}{*}{.147} \\
\hline $\begin{array}{l}\text { The average age of child in months } \\
\text { (SD) } \\
\text { Prosečno trajanje u mesecima (SD) }\end{array}$ & $7.9(6.3)$ & $6.7(4.6)$ & \\
\hline \multicolumn{3}{|l|}{$\begin{array}{l}\text { Breastfeeding - daily frequency } \\
\text { Dojenje - dnevna učestalost }\end{array}$} & \multirow{3}{*}{.711} \\
\hline $\begin{array}{l}<4 \text { times daily }(n=131) \\
<4 \text { puta dnevno }\end{array}$ & $44(33.6)$ & $87(66.4)$ & \\
\hline $\begin{array}{l}\geq 4 \text { times daily }(n=41) \\
\geq 4 \text { puta dnevno }\end{array}$ & $15(36.6)$ & $26(63.4)$ & \\
\hline \multicolumn{3}{|l|}{$\begin{array}{l}\text { Breastfeeding at night } \\
\text { Dojenje u toku noći }\end{array}$} & \multirow{3}{*}{$.005^{*}$} \\
\hline $\begin{array}{l}\text { Yes }(n=58) \\
\text { Da }\end{array}$ & $29(50.0)$ & $29(50.0)$ & \\
\hline $\begin{array}{l}\mathrm{No}(n=134) \\
\mathrm{Ne}\end{array}$ & $38(28.4)$ & 96 (71.6) & \\
\hline \multicolumn{3}{|l|}{$\begin{array}{l}\text { Breastfeeding at night - frequency } \\
\text { Dojenje u toku noći - učestalost }\end{array}$} & \multirow{4}{*}{$.037^{*}$} \\
\hline $\begin{array}{l}\text { Once }(n=30) \\
\text { Jedanput }\end{array}$ & $12(40.0)$ & $18(60.0)$ & \\
\hline $\begin{array}{l}\text { Twice }(n=13) \\
\text { Dvaput }\end{array}$ & $7(53.8)$ & $6(46.2)$ & \\
\hline $\begin{array}{l}\text { Three times or more }(n=15) \\
\text { Tri puta ili više }\end{array}$ & $11(73.3)$ & $4(26.7)$ & \\
\hline \multicolumn{3}{|c|}{$\begin{array}{l}\text { Duration of breastfeeding at night } \\
\text { Uzrast do kojeg je trajalo dojenje tokom noći }\end{array}$} & \multirow[b]{2}{*}{$.012^{*}$} \\
\hline $\begin{array}{l}\text { The average age of child in months } \\
\text { (SD) } \\
\text { Prosečno trajanje u mesecima (SD) }\end{array}$ & $10.3(2.6)$ & $12.8(3.8)$ & \\
\hline \multicolumn{4}{|c|}{$\begin{array}{l}\text { Fisher exact test (breastfeeding, breastfeeding at night), } \chi 2 \text { test to check } \\
\text { the linear growth (frequency of nighttime breastfeeding), binary logistic } \\
\text { regression (Duration of breastfeeding, Duration of breastfeeding at } \\
\text { night) } \\
\text { *Statistically significant results }(p<0.05) \\
\text { Fišerov egzaktni test (dojenje, dojenje noću), } \chi 2 \text { test za proveru linear- } \\
\text { nog rasta (učestalost noćnog dojenja), binarna logistička regresija } \\
\text { (uzrast do kojeg je dete dojeno, uzrast do kojeg je dojeno noću) } \\
\text { *Statistički značajan rezultat }(p<0.05)\end{array}$} \\
\hline
\end{tabular}

the occurrence of S-ECC and socio-economic status of the family, which is consistent with previous studies $[2,9,23]$.

Studies of various researchers have shown that milk and dairy products have multiple benefits for oral health $[24,25]$. Their role in prevention of dental pathology, such as caries and periodontal disease is well documented. It has been showed that milk contains a variety of bioactive peptides, as well calcium that play a key role in maintaining good health of teeth $[24,25]$. Recent study, among preschoolers, shows that children who were not breast-fed were at increased risk for the development of hypoplastic enamel changes [26]. It has also been found that the act of sucking of mother's milk greatly contributes to the proper formation of the stomatognathic system of infants [25]. 
Table 3. Distribution of children according to the use of baby bottle and appearance of S-ECC

Tabela 3. Klasifikacija dece na osnovu upotrebe bočice i pojave cirkularnog karijesa

\begin{tabular}{|c|c|c|c|}
\hline $\begin{array}{l}\text { Variable } \\
\text { Varijable }\end{array}$ & $\begin{array}{l}\text { S-ECC } \\
\text { Cirkularni } \\
\text { karijes } \\
\mathrm{n}(\%)\end{array}$ & $\begin{array}{l}\text { Caries-free } \\
\text { Bez karijesa } \\
n(\%)\end{array}$ & $\mathbf{p}^{\mathrm{a}}$ \\
\hline \multicolumn{3}{|c|}{$\begin{array}{l}\text { Bedtime use of baby bottle with sweetened liquid } \\
\text { (juice, milk porridge, tea) } \\
\text { Upotreba bočice sa zaslađenom tečnošću tokom uspavljivanja } \\
\text { (sok, mleko sa keksom, čaj) }\end{array}$} & \\
\hline $\begin{array}{l}\text { Yes }(n=8) \\
\mathrm{Da}\end{array}$ & $5(62.5)$ & $3(37.5)$ & \multirow{2}{*}{.130} \\
\hline $\begin{array}{l}\mathrm{No}(n=184) \\
\mathrm{Ne}\end{array}$ & $62(33.7)$ & $122(66.3)$ & \\
\hline \multicolumn{3}{|c|}{$\begin{array}{l}\text { Bedtime use of baby bottle with milk } \\
\text { Upotreba bočice sa mlekom tokom uspavljivanja }\end{array}$} & \multirow{3}{*}{$.049^{*}$} \\
\hline $\begin{array}{l}\text { Yes }(n=34) \\
\text { Da }\end{array}$ & $17(50.0)$ & $17(50.0)$ & \\
\hline $\begin{array}{l}\mathrm{No}(n=158) \\
\mathrm{Ne}\end{array}$ & $50(31.6)$ & $108(68.4)$ & \\
\hline \multicolumn{3}{|c|}{$\begin{array}{l}\text { Baby bottle with sweetened liquid during the night } \\
\text { (juice, milk porridge, sweet tea) } \\
\text { Upotreba bočice sa zaslađenom tečnošću tokom noći } \\
\text { (sok, mleko sa keksom, čaj) }\end{array}$} & \multirow{3}{*}{$.014^{*}$} \\
\hline $\begin{array}{l}\text { Yes }(n=17) \\
\text { Da }\end{array}$ & $11(64.7)$ & $6(35.3)$ & \\
\hline $\begin{array}{l}\mathrm{No}(n=175) \\
\mathrm{Ne}\end{array}$ & $56(32.0)$ & $119(68.0)$ & \\
\hline \multicolumn{3}{|c|}{$\begin{array}{l}\text { Baby bottle with milk during the night } \\
\text { Upotreba bočice sa mlekom tokom noći }\end{array}$} & \\
\hline $\begin{array}{l}\text { Yes }(n=24) \\
\text { Da }\end{array}$ & $13(54.2)$ & $11(45.8)$ & \multirow{2}{*}{$.041^{*}$} \\
\hline $\begin{array}{l}\mathrm{No}(n=168) \\
\mathrm{Ne}\end{array}$ & $54(32.1)$ & $114(67.9)$ & \\
\hline \multicolumn{4}{|c|}{$\begin{array}{l}\text { Fisher exact test } \\
\text { *Statistically significant results }(p<0.05) \\
\text { Fišerov egzaktni test } \\
\text { *Statistički značajan rezultat }(p<0.05)\end{array}$} \\
\hline
\end{tabular}

Besides undoubtedly great positive impact on oral health in the literature, there is evidence that human milk under certain conditions, like frequent (on demand) or nighttime feedings after the eruption of primary teeth, leads to acidogenic and cariogenic conditions that contribute to S-ECC [27, 28]. In our study, breastfeeding was not systematically related to the prevalence of S-ECC in the examined children, even frequent daily feedings (more than four times a day) after the eruption of the first primary tooth. Iida et al. found no relationship between breastfeeding, or duration of this habit with the prevalence of S-ECC in children aged two to five years of Mexican-American origin [29]. Nilza and Manoel Ribiero found no reliable scientific evidence to support the hypothesis of human milk cariogenicity, because it is very complex relationship often masked with other potentially cariogenic variables [13]. On the other hand Li et al. and Matea et al. in their research reported significant association between prolonged and frequent breastfeeding on demand and S-ECC $[2,12]$. In the further course of our study we showed that frequent nighttime breastfeeding (or in general practice of nighttime breastfeeding) significantly led to the emergence of S-ECC. Azavedo et al. also showed a link between breastfeeding habits at night (after the age of 12 months) and higher prevalence of S-ECC on a sample of preschool children [23]. Vachirarojpisan et al. reported the prevalence of S-ECC of 58.4\% in children 6 to19 month-old in Thailand. He also showed a significant association between disease and prolonged and frequent breastfeeding, low-income parents, low level of mother's education, high levels of Streptococcus mutans in the mouth, and practicing night meal with bottles [3]. Santos and Soviero in children under 36 months old showed the prevalence of dental caries (including "white spots") was $41.6 \%$. They found significant association between the incidence of dental caries and socio-economic status and practicing night meal (bottle or breast feeding) [20].

A large number of children in our study have been using a baby bottle with milk or other sweetened content at bedtime and during the night and that was significantly associated with the occurrence of S-EEC. This is an indicator of poor oral health education of parents who are not aware about harmful effects of such habits. Therefore we believe there is need for introducing obligatory oral health education of parents. Also dental visit of a child around 12 months of age should become legal obligation in Banja Luka and throughout Republic of Srpska. The American Academy of Pediatric Dentistry (AAPD) and the European Academy of Pediatric Dentistry (EAPD) suggest that regular first dental examination of a child should be done no later than one year of life $[10,30]$. In the scientific literature there is evidence that suggests that counseling and education of parents about nutrition, oral hygiene and other risk factors contribute to lower prevalence of S-ECC [31].

\section{CONCLUSION}

The prevalence of S-ECC in examined children up to 24 month-old in Banja Luka is high and it is associated with nighttime breastfeeding, use of baby bottle with milk during bedtime/nighttime and use of baby bottle with other sweetened content during nighttime after eruption of the first primary teeth. It is necessary to introduce mandatory first dental examination of a child around the first year of life as well as to organize oral health-education of parents.

\section{REFERENCES}

1. Kumarihamy SL, Subasinghe LD, Jayasekara P, Kularatna SM, Palipana PD. The prevalence of Early Childhood Caries in 1-2 years old in a semi-urban area of Sri Lanka. BMC Res Notes. 2011; 4:336. [DOI: 10.1186/1756-0500-4-336] [PMID: 21902840]

2. Li Y, Navia JM, Bian JY. Caries experience in deciduous dentition of rural Chinese children 3-5 years old in relation to the presence or absence of enamel hypoplasia. Caries Res. 1996; 30(1):8-15. [DOI:10.1159/000262130] [PMID: 8850577]

3. Vachirarojpisan T, Shinada K, Kawaguchi Y, Laungwechakan P, Somkote T, Detsomboonrat P. Early childhood caries in children aged 6-19 months. Community Dent Oral Epidemiol. 2004; 32(2):133-42. [DOI: 10.1111/j.0301-5661.2004.00145.x] [PMID: 15061862]

4. Al-Jewair TS, Leake JL. The Prevalence and Risks of Early Childhood Caries (ECC) in Toronto, Canada. J Contep Dent Pract. 2010; 11(5):001-002. [PMID: 20978718] 
5. Finlayson TL, Siefert K, Ismail Al, Sohn W. Psychosocial factors and Early Childhood Caries among low-income African-American children in Detroit. Community Dent Oral Epidemiol. 2007; 35(6):439448. [DOI: 10.1111/j.1600-0528.2006.00352.x] [PMID: 18039285]

6. Rosenblatt A, Zarzar P. Breast-feeding and early childhood caries: an assessment among Brazilian infants. Int J Paediatr Dent. 2004; 14(6):439-45. [DOI: 10.1111/j.1365-263X.2004.00569.x] [PMID: 15525313]

7. Mohebbi SZ, Virtanen JI, Vahid-Golpayegani M, Vehkalahti MM.Early childhood caries and dental plaque among 1-3-year-olds in Tehran, Iran. 2006; 24(4):177-81. [DOI: 10.4103/0970-4388.28073] [PMID: 17183180]

8. Harris R, Nicoll AD, Adair PM, Pine CM. Risk factors for dental caries in young children: a systematic review of the literature. Community Dent Health. 2004; 21(1):71-85. [PMID: 15072476]

9. Leong PM, Gussy MG, Barrow SY, de Silva-Sanigorski A, Waters E. A systematic review of risk factors during first year of life for early childhood caries. Int J Paediatr Dent. 2013; 23(4):235-50. [DOl: 10.1111/j.1365-263X.2012.01260.x] [PMID: 22925469]

10. American Academy of Pediatrics Dentistry. Policy on Early Childhood Caries (ECC): Classifications, consequences, and preventive strategies. 2011. Retrieved from: http://www.aapd.org/media/Policies_Guidelines/P_ECCClassifications.pdf. Accessed March 20th $201 \overline{6}$.

11. Berkowitz RJ. Causes, treatment and prevention of early childhood caries: a microbiologic perspective. Journal-Canadian Dental Association. 2003; 69(5):304-7. [PMID: 12734024]

12. Matee MI, Mikx FH, Maselle SY, Van Palenstein Helderman WH. Rampant caries and linear hypoplasia. Caries research. 1992; 26(3):205-8. [DOI: 10.1159/000261444] [PMID: 1628296]

13. Ribeiro NM, Ribeiro MA. Breastfeeding and early childhood caries: a critical review. Jornal de Pediatria. 2004; 80(5):199-210. [DOl: 10.1590/S0021-75572004000700012] [PMID: 15583771]

14. Diet, nutrition and the prevention of chronic diseases: report of a joint WHO/FAO expert consultation. Geneva: World Health Organization; Geneva 2003. (WHO Tehcnical Report Series 916), Available at: http://whqlibdoc.who.int/trs/who_trs_916.pdf. Accessed March 29th 2016.

15. Kaste LM, Gift HC. Inappropriate Infant Bottle Feeding. Status of the Healthy People 2000 Objective. Archives of pediatrics \& adolescent medicine. 1995; 149(7):786-791. [DOI: 10.1001/archpedi.1995.02170200076012] [PMID: 7795770]

16. American Academy of Pediatric Dentistry. Guideline on Caries-risk Assessment and Management for Infants, Children and Adolescents, Council of Clinical Affairs. 2002. Available at: http://www.aapd.org/ media/Policies_Guidelines/G_CariesRiskAssessment.pdf. Accessed May 30th 2016.

17. Ramos-Gomez FJ, Crystal YO, Ng MW, Crall JJ, Featherstone JD. Pediatric dental care: prevention and management protocols based on caries risk assessment. J Calif Dent Assoc. 2010; 38(10):746-761. [PMID: 21162350]

18. Ismail Al, Sohn W, Tellez M, Amaya A, Sen A, Hasson H, et al. The International Caries Detection and Assessment System (ICDAS): an integrated system for measuring dental caries. Community Dent Oral Epidemiol. 2007; 35:170-178. [DOl: 10.1111/j.1600-0528.2007.00347.x] [PMID: 17518963]

19. Dini EL, Holt RD, Bedi R. Caries and its association with infant feeding and oral health-related behaviours in 3-4-year-old Brazilian children. Community Dent Oral Epidemiol. 2000; 28(4):241-8.

[DOI: 10.1034/j.1600-0528.2000.280401.x] [PMID: 10901402]

20. Santos AP, Soviero VM. Caries prevalence and risk factors among children aged 0 to 36 months. Pesquisa Odontológica Brasileira. 2002; 16(3):203-8. [DOI: 10.1590/S1517-74912002000300004] [PMID: 12386680]

21. Obradovic M. Oral health of children up to 6 years of age in Center for pre-school education in the city of Banja Luka. Master Thesis, Faculty of Medicine Banja Luka, Bosnia and Herzegovina. 2010.

22. Republic of Srpska Institute for Statistics, Banja Luka, Republic of Srpska, Average wages of employees (KM); c2002-2015 (cited 2016 May 16). Available at: http://www.rzs.rs.ba/. Accessed May 16th 2016.

23. Azevedo TD, Bezerra AC, de Toledo OA. Feeding habits and severe early childhood caries in Brazilian preschool children. Pediatric Dentistry. 2005; 27(1):28-33. [PMID: 15839392]

24. Merritt J, Qi F, Shi W. Milk helps build strong teeth and promotes oral health. J Calif Dent Assoc. 2006; 34(5):361-6. [PMID: 16900979]

25. Wang XT, Ge LH. Influence of feeding patterns on the development of teeth, dentition and jaw in children. Beijing da xue xue bao. Yi xue ban= Journal of Peking University. Health sciences. 2015; 47(1):191-5. [PMID: 25686355]

26. Kato T, Yorifuji T, Yamakawa M, Inoue S, Saito K, Doi H, et al. Association of breast feeding with early childhood dental caries: Japanese population-based study. BMJ open. 2015; 5(3):e006982. [DOI: 10.1136/bmjopen-2014-006982] [PMID: 25795694]

27. Çolak H, Dülgergil ÇT, Dalli M, Hamidi MM. Early childhood caries update: a review of causes, diagnoses, and treatments. Journal of Natural Science, Biology and Medicine. 2013; 4(1):29. [DOI: 10.4103/0976-9668.107257] [PMID: 23633832]

28. Nainar SH, Mohummed S. Role of infant feeding practices on the dental health of children. Clinical pediatrics. 2004; 43(2):129. [DOI: 10.1177/000992280404300202] [PMID: 15024436]

29. lida H, Auinger P, Billings RJ, Weitzman M. Association between infant breastfeeding and early childhood caries in the United States. Pediatrics. 2007; 120(4):e944-52. [DOl: 10.1542/peds.2006-0124] [PMID: 17908749]

30. Guidelines on Prevention of Early Childhood Caries: An EAPD Policy Document, Europian Academy of Paediatric Dentistry, 2008. Available at: http://www.eapd.eu/dat/1722f50d/file.pdf. Accessed March 24th 2016.

31. Ismail Al, Nainar SM, Sohn W. Children's first dental visit: attitudes and practices of US pediatricians and family physicians. Pediatric dentistry. 2003; 25(5):425-30. [PMID: 14649605]

Received: 14.06.2016 • Accepted: 23.08.2016 


\title{
Povezanost navika u ishrani sa pojavom cirkularnog karijesa u uzrastu dece do 24 meseca
}

\author{
Marija Obradović, Olivera Dolić, Jovan Vojinović, Slava Sukara \\ Univerzitet u Banjoj Luci, Medicinski fakultet, Katedra za dečju i preventivnu stomatologiju, Banja Luka, Republika Srpska, Bosna i \\ Hercegovina
}

\begin{abstract}
KRATAK SADRŽAJ
Uvod Ishrana dece u prve dve godine života bazirana je uglavnom na čestim, tečnim, kašastim i neretko zaslađenim obrocima, koji nažalost mogu biti dobra podloga za razvoj cirkularnog karijesa. Cilj istraživanja je bio da se ispita uticaj navika u ishrani na pojavu karijesa ranog detinjstva, u uzrastu dece do 24 meseca života u Banjoj Luci u Bosni i Hercegovini.

Materijal i metode Istraživanje je sprovedeno po principu analitičke studije preseka, koja je obuhvatala reprezentativni uzorak od 192 deteta. Pre stomatološkog pregleda, roditelj (staratelj) je anketiran o generalijama, sociodemografskim karakteristikama porodice i prehrambenim navikama deteta. Anketa je sprovedena u vidu intervjua („licem u lice“). Ispitanici su podeljeni u dve grupe: prva grupa - deca sa cirkularnim karijesom, i druga grupa - deca bez karijesa. Za statističku analizu i prezentovanje rezultata korišćen je SPSS 16.0 za Windows, MS Office Word i MS Office Excel.

Rezultati U ispitivanoj grupi 34,9\% dece je obolelo od cirkularnog karijesa. Ispitivanjem navika u ishrani nađeno je da deca koja su dojena noću nakon nicanja prvog zuba u 50\% slučajeva imaju KRD, što je bilo statistički značajno $(p=0,005)$. Kao značajan faktor rizika identifikovana je i upotreba bočice sa mlekom ili drugim zaslađenim sadržajem tokom uspavljivanja i u toku noći $(p<0,05)$. Zaključak Navika noćnog dojenja, te upotrebe bočice sa mlekom prilikom uspavljivanja/tokom noći ili bočice sa drugim zaslađenim sadržajem u toku noći, a nakon nicanja prvog mlečnog zuba, veoma su značajni faktori rizika za pojavu cirkularnog karijesa kod ispitivane dece.
\end{abstract}

Ključne reči: dojenje; cirkularni karijes; noćno dojenje; bočica; faktori rizika

\section{UVOD}

Rano detinjstvo je ključno za razvoj i unapređenje oralnog zdravlja. Karijes ranog detinjstva (KRD) veoma je značajan i jako veliki javni zdravstveni problem u svetu [1-7]. Prema istraživanjima, to je jedno od najčešćih hroničnih zaraznih oboljenja u detinjstvu, koje je zbog multifaktorijalne etiologije veoma teško kontrolisati $[8,9]$.

Agresivnija forma KRD - cirkularni karijes (Severe early childhood caries - SECC) može se javiti čim se zub pojavi u ustima, sa lokalizacijom na karijes imunim mestima, odnosno glatkim površinama zuba [10]. Oboljenje započinje kao kredasto beličasta promena na vestibularnoj površini gleđi uz gingivu, mada neretko i na oralnoj strani maksilarnih mlečnih sekutića. Razaranje zuba može dosta brzo da napreduje i zahvati ostale grupe zuba. Ukoliko se detetu ne pruži odgovarajuća terapija, oboljenje napreduje ka pulpi, širi se i dovodi do pojave bola i drugih komplikacija.

Kao i ostale forme karijesa, cirkularni karijes se razvija interakcijom tri glavna faktora, i to prisustvom kariogenih mikroorganizama, fermentabilnih ugljikohidrata i zuba, tokom određenog vremenskog perioda [11]. U obzir se moraju uzeti i specifičnosti koje su vezane za rani uzrast, kao što je nezreo odbrambeni sistem, tek iznikli zubi koji su u fazi posteruptivne mineralizacije, hipoplastične promene, poseban vid ishrane (pretežno tečna bazirana na podojima ili upotrebi mlečne formule putem flašice) [12,13]. Pored navedenih, postoji još čitav niz faktora rizika koji na indirektan način doprinose obolevanju mlečnih zuba, a mnogi se još uvek istražuju [8-10].

Dojenje predstavlja prirodan, poželjan način ishrane za novorođenče i nesumljivo ima veliki značaj za celokupno zdravlje i razvoj. Majčino mleko je specifično i po sastavu idealno odgovara ljudskoj vrsti, dok se zamene različitog porekla (adaptirane mlečne formule, mleko životinjskog porekla) umnogome razlikuju po sadržaju. Dojenje ima višestruki značaj za pravilan rast, obezbeđuje optimalne nutritivne potrebe, imunološku zaštitu dojenčeta, a takođe i minimizira ekonomski uticaj na porodicu. Od strane Svetske zdravstvene organizacije preporučeno je do 24 meseca života [14]. Međutim, Američka akademija za dečju stomatologiju (American Academy of Pediatric Dentistry - AAPD) preporučuje da se sa dojenjem prestane oko 12. meseca života deteta, pa čak i ranije - nakon što prvi zub nikne (oko šestog meseca), jer ova navika predstavlja rizik za razvoj cirkularnog karijesa (S-ECC) [10].

Ishrana dece u prve dve godine zasnovana je uglavnom na čestim, tečnim, kašastim i neretko zaslađenim obrocima. Posebnu ulogu u etiologiji karijesa u ranom detinjstvu ima neodgovarajuća upotreba bočice i njena prolongirana upotreba tokom noćnog sna, odnosno njen dodatno zaslađen sadržaj. Kada dete zaspi, tečnost se razliva po maksilarnim sekutićima, predstavljajući izvanrednu podlogu za razvoj kariogenih bakterija, naročito tokom noći, kada se smanjuje lučenje pljuvačke i izostaje njena puferska, antimikrobna i uloga samočišćenja [15].

U Banjoj Luci, pa i celoj Republici Srpskoj, ne postoji organizovani preventivni program u stomatologiji. Ne postoji sistematizovan zdravstveno-vaspitni rad sa roditeljima, nedostaju podaci vezani za stanje u oralnom zdravlju i faktorima rizika u najranijem uzrastu, jer ni praksa prvog redovnog stomatološkog pregleda oko godine dana nije utemeljena. Prvi stomatološki pregled je obavezan tek pri upisu u osnovnu školu.

Cilj ovog rada je bio da se utvrdi uticaj navika u ishrani na pojavu karijesa ranog detinjstva, u uzrastu dece do 24 meseca života u Banjoj Luci, Bosna i Hercegovina.

\section{METODE RADA}

Istraživanje je sprovedeno među decom uzrasta do 24 meseca, u periodu između jula 2012. godine i jula 2013. godine. Ispitivanje je realizovano kao retrospektivna studija preseka, koja je 
obuhvatila 192 deteta oba pola. Reprezentativni uzorak je činilo $10 \%$ (nešto više) dece od 1820 rođenih i nastanjenih tokom 2011/2012. godine u gradu Banja Luka. Istraživanje je sprovedeno u Javnoj ustanovi Dom zdravlja Banja Luka. Pre započinjanja istraživanja dobijena je potrebna saglasnost direktora i Etičkog odbora Doma zdravlja Banja Luka. Uslovi za uključivanje ispitanika $\mathrm{u}$ istraživanje su bili prisustvo najmanje dva u potpunosti iznikla mlečna zuba kod zdravog deteta, kao i pristanak roditelja za učešće. Ispitanici su odabrani metodom slučajnog izbora. Zdrava deca koja su posećivala redovne pedijatrijske kontrole u Savetovalištu za decu i vakcinisana u Vakcinacionom centru Doma zdravlja Banja Luka upućivana su na prvi stomatološki pregled kod specijaliste dečje i preventivne stomatologije, te evaluaciju faktora rizika za nastanak karijesa ranog detinjstva. Prvi stomatološki pregled dece je vršen u posebnoj ambulanti u sklopu Savetovališta od strane jednog istraživača. Svako dete koje je preporučeno od strane pedijatra je pregledano, ali jedino ona koja su prošla inkluzioni kriterijum bila su uključena u dalji tok istraživanja.

Pre stomatološkog pregleda, roditelj (staratelj) je anketiran. Popunjeno je i naknadno analizirano ukupno 192 ankete. Anketa je sprovedena u vidu intervjua („licem u lice“) od strane jednog istraživača. Za potrebe ovog ispitivanja formiran je Istraživački obrazac koji je sadržao dva dela. U prvom delu su se nalazila pitanja vezana za generalije pacijenta, sociodemografske podatke, dijetetske podatke kao što je dojenje i upotreba flašice. Drugi deo bio je predviđen za evidentiranje zdravstvenog stanja zuba ispitanika. Pitanja vezana za prehrambene navike (dojenje i upotreba flašice) kao moguće faktore rizika za nastanak cirkularnog karijesa odnosila su se za period nakon nicanja prvog mlečnog zuba. Mleko u bočici se odnosilo na mlečne formule ili mleko životinjskog porekla (kravlje), a ostali zaslađeni sadržaj je podrazumevao sokove, mleko sa keksom, zaslađeni čaj ili kompot. Istraživački obrazac je formiran prema smernicama Američke akademije za dečju stomatologiju (AAPD) [16].

Nakon kompletiranja upitnika vršeni su stomatološki pregledi dece u za to predviđenoj prostoriji sa dobrim prirodnim osvetljenjem. Pošto se radilo o sasvim maloj deci, stomatološki pregledi su vršeni tako da dete leži trupom i nogama roditelju u krilu, dok je glava deteta položena stomatologu u krilo (roditelj i stomatolog sede jedan nasuprot drugog, u takozvanoj „knee to knee“ poziciji) [17]. Pregledi su rađeni pomoću stomatološkog ogledalca i CPI parodontološke sonde (CPI - Community Periodontal Index). Sterilni tupferi gaze su korišćeni za posušivanje zuba, te uklanjanje dentalnog biofilma. Status zuba dece je evidentiran u za to predviđeni deo Istraživačkog obrasca. Kariozne promene kod dece su dijagnostikovane pomoću International Caries Detection and Assessment System (ICDAS), koji služi za dijagnostiku i evidenciju karioznih lezija od početnih promena u gleđi bez formiranog kaviteta („bele mrlje“) do uočljivih karioznih kaviteta [18]. Svaka površina zuba je pregledana i evidentirana u Istraživački obrazac. Evidentirani su zubi koji su u potpunosti iznikli i čije su sve površine krunice bile vidljive.

Nakon prikupljanja podataka u svrhu dalje analize i procene faktora rizika ispitanici su podeljeni u dve grupe. Prvu grupu su činila deca koja su imala cirkularni karijes (S-ECC), odnosno najmanje jednu aktivnu početnu karioznu leziju na glatkim površinama maksilarnih frontalnih zuba (AAPD) [10], a drugu grupu su činili potpuno zdravi ispitanici bez karijesa (caries-free).
Za statističku analizu i prezentovanje rezultata korišten je SPSS 16.0 za Windows, MS Office Word i MS Office Excel. Dobijeni rezultati su analizirani statistički pomoću Fišerovog egzaktnog testa, $\chi 2$ testa (za proveru linearnog rasta), kao i binarne logističke regresije. Vrednosti $p<0,05$ su se smatrale statistički značajnim.

\section{REZULTATI}

Ukupan uzorak je činilo 192 dece uzrasta do 24 meseca (+/- 3 meseca). Pregledano je ukupno 99 (51,6\%) dečaka i 93 (48,4\%) devojčice. Prevalencija karijesa u ispitivanom uzorku iznosila je $34,9 \%$.

Sociodemografske karakteristike porodice prezentovane su u Tabeli 1. Većina majki ispitivane dece $(n=117)$ imale su srednjoškolsko obrazovanje ili niže, što je bilo značajno za pojavu karioznog oboljenja kod dece. Oko 71,87\% očeva ispitivane dece takođe je imalo srednjoškolsko ili niže obrazovanje, a 79,69\% porodica imalo je mesečna primanja ispod $1600 \mathrm{KM}(<818$, 06 evra).

Većina ispitivane dece, $89,58 \%$, hranjena je na prirodan način $(n=172)$ minimalno jedan mesec. Statistički značajnim se nije pokazala razlika u pojavi karioznog oboljenja kod dece koja su dojena (34,3\%) ili nisu (40.0\%) (Tabela 2).

Ispitivanjem učestalosti dnevnih podoja nakon nicanja prvog zuba pokazano je da su deca koja su dojena četiri puta dnevno ili češće $(n=41)$ u blago većem (ne značajnom) procentu obolela od cirkularnog karijesa $(36,6 \%)$ u odnosu na decu koja su imala manji broj dnevnih podoja $(33,6 \%)$.

Oko 50\% dece koja su dojena tokom noći imala su karijes (Tabela 2), a 73,3\% obolelih od karijesa je dojeno više od dva puta u toku noći. Ova razlika je bila statistički značajna.

Pojava karijesa u zavisnosti od uspavljivanja i pijenja iz bočice tokom noći je prezentovana u Tabeli 3, gde se vidi da 50\% dece koja se uspavljuju pijenjem mleka iz flašice imaju karijes. Deca koja su konzumirala flašicu sa zaslađenom tečnošću $(64,7 \%)$ ili mlekom $(54,2 \%)$ tokom noći takođe su u značajno većem procentu imala kariozno oboljenje.

\section{DISKUSIJA}

Prevalencija karijesa ranog detinjstva se kreće od 1\% do 70\% u različitim delovima sveta i na nju utiču mnogi faktori $[2,3$, 19, 20]. Istraživanje rađeno u Banjoj Luci od 2008. do 2010. godine na deci koja pohađaju Centar za predškolsko obrazovanje i vaspitanje, gde su u studiji bila uključena deca uzrasta od dve do šest godina, pokazuje visoku prevalenciju karijesa, koja je iznosila 35,35\% (gde je karijes dijagnostikovan u formi već formiranog karioznog kaviteta). Najveći procenat obolelih zuba je bio nesaniran, čak 92,69\% [21]. Međutim, u ovom istraživanju nije obuhvaćen rani uzrast (do 24 meseca života), koji je sa stanovišta primarne prevencije najvažniji, a ni početne kariozne lezije nisu bile registrovane.

Leong i saradnici potvrđuju da činioci koji se javljaju u prvoj godini života snažno utiču na iskustvo vezano za rani karijes, što se između ostalog posebno odnosi na navike u ishrani deteta [9].

Prevalencija cirkularnog karijesa u ovom istraživanju izuzetno je visoka i iznosi 34,9\% svih ispitanika starosti do 24 meseca. 
Većina dece je poticala iz porodica čija su primanja ispod prosečnih, s obzirom na to da je čak 79,68\% ispitivanih porodica imalo mesečna primanja manja od $1600 \mathrm{KM}$ (ispod 818,06 evra), dok je prema podacima Republičkog zavoda za statistiku RS prosečna mesečna neto plata u Republici Srpskoj iznosila oko 825 KM (421,81 evra) [22]. Ovo istraživanje pokazuje značajnu vezu između pojave cirkularnog karijesa i materijalnog statusa porodice, što je u skladu sa ranijim istraživanjima $[2,9,23]$.

Studije različitih istraživača su pokazale da mleko i mlečni proizvodi imaju višestruku korist za oralno zdravlje [24, 25]. Dokazana je njihova uloga u sprečavanju stomatološke patologije, kao što su karijes i parodontopatije, time što se u mleku nalaze razni bioaktivni peptidi, kao i kalcijum, koji imaju ključnu funkciju u održavanju zdravlja zuba [24, 25]. Novije istraživanje na deci predškolskog uzrasta pokazuje da deca koja nisu hranjena majčinim mlekom imaju veći rizik za razvoj hipoplastičnih promena u gleđi [26]. Takođe, akt sisanja u velikoj meri doprinosi pravilnom formiranju stomatognatnog sistema dojenčeta [25]. Međutim, pored nesumnjivo velikog značaja za oralno zdravlje, u literaturi postoje dokazi da majčino mleko $\mathrm{u}$ određenim uslovima čestih (na zahtev) ili noćnih podoja nakon nicanja zuba dovodi do stvaranja acidogenih i kariogenih uslova koji doprinose nastanku cirkularnog karijesa [27, 28].

$\mathrm{U}$ ovom istraživanju dojenje nije bilo sistematski povezano sa pojavom cirkularnog karijesa kod ispitivane dece, čak ni učestaliji dnevni podoji (više od četiri puta dnevno) nakon nicanja prvog mlečnog zuba.

Iida i saradnici ne nalaze vezu između dojenja, niti dužine trajanja ove navike sa pojavom cirkularnog karijesa kod dece uzrasta od dve do pet godina meksičko-američkog porekla [29]. Nilza i Manoel Ribiero potvrđuju da ne postoje pouzdani naučni dokazi koji podržavaju hipotezu o kariogenosti humanog mleka, te da je u pitanju vrlo kompleksna veza koja je često maskirana mnoštvom drugih potencijalno kariogenih varijabli [13].

Sa druge strane, Li i saradnici, a takođe Matee i saradnici u svojim istraživanjima nalaze vrlo značajnu vezu između prolongiranog i frekventnog dojenja deteta na zahtev i pojave cirkularnog karijesa $[2,12]$.

U daljem toku ovog istraživanja je pokazano da su u slučaju dojenja tokom noći (nakon nicanja prvog zuba) sve tri ispitivane varijable ukazale na to da je češće noćno dojenje (ili uopšte, praksa noćnog dojenja) značajno dovodila do pojave cirkularnog karijesa kod ispitivane dece.
Azavedo i saradnici takođe pokazuju vezu između navike dojenja noću (nakon navršenih 12 meseci) i češće pojave cirkularnog karijesa na uzorku dece predškolskog uzrasta [23].

Vachirarojpisan i saradnici u oblasti U-thong, Tajland, na uzrastu dece od 6 do 19 meseci nalaze pojavu cirkularnog karijesa u procentu od $58,4 \%$, te takođe pokazuju značajnu povezanost oboljenja sa prolongiranim i čestim dojenjem, niskim primanjima roditelja, niskim stepenom obrazovanja majke, visokim nivoom Streptococcus mutansa u ustima, te praksom noćnog obroka putem flašice [3].

Santos i Soviero kod dece uzrasta do 36 meseci ukazuju na prevalenciju karijesa (uključujući i „bele mrlje“) od 41,6\%. Nisu pronašli značajnu povezanost između učestalosti karijesa i socioekonomskog statusa, odnosno praktikovanja noćnog obroka (flašicom ili dojenjem) [20].

Veliki je broj dece koji je za uspavljivanje ili tokom noći koristio flašicu sa mlekom ili drugim zaslađenim sadržajem, što ukazuje na needukovanost roditelja o štetnosti takvih navika, koje su značajno bile povezane sa nastankom cirkularnog karijesa. Na osnovu ovih nalaza je važno naglasiti da postoji neophodnost oralno-zdravstvenog vaspitanja roditelja, odnosno utvrđivanje zakonski obaveznog prvog stomatološkog pregleda deteta oko 12 . meseca života u Banjoj Luci, ali i celoj Republici Srpskoj.

American Academy of Pediatric Dentistry - AAPD i European Academy of Pediatric Dentistry - EAPD ukazuju da redovan prvi stomatološki pregled deteta treba obaviti najkasnije do navršenih godinu dana života $[10,30]$. U naučnoj literaturi postoje dokazi koji sugerišu da savetovanje i upoznavanje roditelja o pravilnim navikama u ishrani, oralnoj higijeni, kao i rizicima za nastanak karijesa ranog detinjstva doprinose manjoj stopi pojave oboljenja [31].

\section{ZAKLJUČAK}

Prevalencija cirkularnog karijesa dece uzrasta do 24 meseca u Banjoj Luci je visoka. Navika noćnog dojenja i korišćenja flašice sa mlekom u svrhu uspavljivanja i tokom noći, kao i upotreba flašice sa zaslađenim sadržajem tokom noći nakon nicanja prvog mlečnog zuba je značajan faktor rizika za pojavu cirkularnog karijesa. Neophodno je uvođenje obaveznog prvog stomatološkog pregleda deteta do godine dana i organizovanje zdravstveno-vaspitnog rada sa roditeljima. 